\title{
The Effectiveness of Skimming and Scanning Strategies In Improving Comprehension and Reading Speed Rates for the Students of English Study Program
}

\author{
Iwan Fauzi \\ FKIP Universitas Palangka Raya \\ i_fauzi@edu.upr.ac.id \\ DOI: http://dx.doi.org/10.18326/rgt.v11i1.101-120
}

\section{Submission Track: \\ Received:$$
\text { 28-03-2018 }
$$ \\ Final Revision \\ 05-05-2018 \\ Available online: \\ 03-06-2018}

Corresponding Author:

Iwan Fauzi

I_fauzi@edu.upr.ac.id

\section{ABSTRACT}

This research was aimed to know the effectiveness of skimming and scanning strategies to improve students' reading ability indicated by their competence to comprehend texts and their performance in the speed of reading. Pre-test and post-test control group design was used in this research. Third year students of English Study Programme of FKIP of Palangka Raya University were taken for the research subject. There were 54 students taken which were equally in number grouped into an experimental group and a control group. Both groups were considered to be equal in reading performance with regard to the result of pre-test carried out before the experiment. Experimental group was the class where the researcher supervised it, and control group was a group where he did not supervise it with the experiments. The result showed that scores of reading tasks given to the experimental group $(M=75.56, S D=4.07)$ were significantly higher than the control group $(M=64.82, S D=3.72) t=9.928, p=.000$. 
Meanwhile, the speed of reading rates of the experimental group $(M=274.07, S D=32.06)$ was also significantly higher than the control group $\quad(M=204.29, \quad S D=21.98) \quad t=9.325$, $p=.000$. Either comprehension or speed rates performed by the experimental group showed more excellent than its counterpart. Based on these findings, skimming and scanning strategies were undeniably effective to improve students' comprehension in reading and efficient to boost their speed of reading.

Keywords: reading comprehension; reading speed; skimming; scanning

\section{INTRODUCTION}

In learning English, students have to master four basic language skills of the target language. Those basic skills are listening, speaking, reading, and writing. Speaking and writing are language production (productive skills), while listening and reading belong to language comprehension (receptive skills). Among those four skills, reading is vital in language comprehension.

Reading is one of the four skills that students should learn and care of. Reading process means not only "read" but tries to make interaction between the reader and the text. It is a constructive process that can help students to acquire new knowledge of language, experience about life and so on. Simply, reading is defined as "the active process of understanding print and graphic texts" (Souhila, 2014: 4). It is deals with how the readers can convey the meaning through the written symbols and process them into their mind.

In more classical term, reading defines as the meaningful interpretation of printed or written verbal symbols (Nuttal, 1982: 42). This definition indicates that reading is a result of the interaction between the perception of graphic symbols that represent language and the reader's language skill, cognitive skill and knowledge. Therefore, reading process also 
makes connection between a text, a reader and social context with in which the activity take place. This is in line with Hudelson in Murcia (2001: 154) that reading process involves the reader's acting on or interpreting the text and the interpretation is influenced by the reader's past experiences, language background, and cultural frame work, as well as the reader's purpose for reading.

In addition, Howart (2006) in Susanti (2013) cites that reading is, of course, just as communicative as any other form of language. It means that in reading there is an interaction between the writer and the readers through the texts. The writer tries to encode the messages to the reader, then the reader tries to decode the messages sent by the writer. Thus, it can be inferred that reading is a complex activity process which is very important involving the language and thought in order to get meaningful message, or information sent by the writer through printed language such as graphic symbols, or written verbal symbols.

In order to understand the way of people read, two types of reading which are mostly well-known and mostly applied by readers; those are intensive and extensive reading. The former refers to a high degree of comprehension and retention over a long period of time, in other words, it is reading in depth or carefully to comprehend a given text for example; studying it line by line, using the dictionary, comparing, analysing, translating, and retaining every expression that it contains. Brown (1994: 400) explains that intensive reading "calls attention to grammatical forms, discourse markers, and the surface structure details for the purpose of understanding literal meaning, implications, rhetorical relationships, and the like". Therefore, intensive reading is reading for a high degree of comprehension and retention over a long period of time. 
In term of extensive reading, Bamford et al (2004: 3-4) defined "Extensive reading is a language teaching procedures where learners are supposed to read large quantities of materials or long texts for global understanding, the principal goal being obtaining pleasure from the text". According to Liana's Extensive Reading Journals (2011) in Souhila (2014:4), it is "reading as much as possible, for your own pleasure, at a difficulty level at which you can read smoothly and quickly without looking up words or translating to English as you go". So, we can say that extensive reading is connected to student choice and pleasure in reading in order to reach enjoyment.

In educational system, most of EFL learners face many problems especially in comprehension of written materials when reading. According to them, understanding the meaning of texts can be a great challenge i.e. they are able to understand each word and even each sentence; but unfortunately, they fail to achieve the meaning of text as a whole. For that reason, many psychologists and researchers, to mention few such as Beale (2013), Macleod (2013), and Brown (1994) assume that those who always struggle and find reading comprehension as a problematic issue is due to the fact that most of students lack their reading strategies that may help them to overcome their reading problems.

Furthermore, there are much evidence that have been shown on the importance of reading strategies and their effective role in enhancing and developing reading comprehension. Mc Namara et al (2009: 218) views that "reading strategies are more useful and beneficial for learners who show lack of knowledge in the domain of reading, as well as those with lower reading skill, these kinds of learners are strongly needed to these strategies to achieve reading comprehension". Therefore, the continuous use of reading strategies 
will lead the readers to become skilled and later they will be able to utilize the reading skills acquired without conscious efforts.

In the area of reading strategy studies, many researchers have utilized different types of strategies; these last are more effective, useful and beneficial ones for students which some of them are as follows: predicting, skimming, scanning, inferring, guessing the meaning of new words, selfmonitoring, and summarizing. This study prefers to deal with skimming and scanning strategies since both strategies are the most necessary ones to be implemented in reading. Besides, it is also important to contribute more studies about skimming and scanning in reading skill as this study was carried out.

One of the most effective methods for beginning the kind of thoughtful reading necessary for academic work is to get a general overview of the text before beginning to read it in detail. Beale (2013) in Abdurrahman (2014: 169) wrote ideas about speed reading strategies as "people who know how to skim and scan are flexible readers. They read according to their purpose and get information they need quickly without wasting time. They do not need everything which is not important to read in increasing their reading speed. Their skill lies in knowing what specific information to read and which method to read". Relating to this situation, strategies of skimming and scanning are well-known and help students to improve their speed as well. Macleod (2013) in Abdel rahman (2014) wrote that skimming involves a through overview of a text and implies a reading competence. When reading, a reader needs to know every single word in the text. Some of the words are not so important to understand that the reader may neglect them, they sometimes do not really connect to the idea being searched. Skimming is one of strategies that require readers to read quickly in order to get an overview 
or the general idea or gist of a section. According to Djuwarsih (2006:14), skimming is a skill of getting general idea of a text. It means that we need only short time to read the text. It is because general idea of the text usually is located at certain lines or certain sentences of the text. In other word, we only need to read certain parts or lines of the text quickly. It is also supported by Djuharie (2008:12) who claimed that skimming refers to look at the text quickly for getting the main idea from the text. It may be true that by using skimming, readers don't need to read the whole text. They only need to look at the text quickly and find the main idea of the text. So, they wouldn't waste their time when they are reading the text.

In addition, Hanckock in Simanjuntak (1989: 58) also says that in preview skimming a reader reads the introductory information, the heading and subheading, and the summary, if one is provided. After skimming, decide whether to read the material more thoroughly, and select the appropriate speed which to read. Skimming to get an overview is an important skill for students. By skimming to get the "gist" of the material, the students are able to cover all of it. According to Liao (2011) in Hong (2013: 2), skimming is done at a speed three to four times faster than normal reading. People often skim when they have lots of material to read in a limited amount of time.

To define its counterpart, scanning is more a limited activity, only retrieving information relevant to a purpose. Brown (1994: 283) suggested that "perhaps the two most valuable reading strategies for learners as well as native speakers are skimming and scanning". In reading, the students searching for some particular piece of information in the text quickly and practice to think of clues move their eyes rapidly. Vaezi (2006: 5) states that scanning is reading rapidly to find specific a piece of information. According to Casey (2003: 2), scanning is a device used to locate details-specific information that may be asked at the end of the assignment. Therefore, 
scanning is very useful for students to find specific information to get answers from the questions in the assignment or exam, and minimize their time to answer the questions in the text. Brown (2001:308) said that scanning means quickly searching for some particular pieces of information in a text. It is said that by using scanning, reader only needs to extract specific information without reading throughout the whole text. Scanning is usually used to look for names or dates, or to list a certain number of supporting details. This is in line with Djuwarsih (2006:14) who stated scanning is a reading skill in getting specific information from a text. When we want to know some specific information from the text, we should not read the whole passage carefully. We need only to locate the information we want from the passage. So that it can help readers get certain information from the text easily. It is because readers usually tend to read the whole text carefully.

Many studies investigated those both reading strategies and they proved that skimming and scanning can improve students' achievement to their better comprehension and also better speed rates in reading. Rababa'h (1991), for instance, conducted a study to find the effect of using skimming and scanning in the first secondary science students. He conducted his study on male and female students. The results of the study showed that the experimental group has a high significant use of skimming and scanning strategies. The difference with the control group was due to the training on the use of the speed reading strategies.

Then, Abdelrahman and Bsharah (2014) carried out a study to find the effect of speed reading strategies on developing reading comprehension among second secondary literary stream students in English language. Their study consists of 42 students assigned into two groups who were chosen randomly from schools, a controlled group (21) students, and an experimental 
(21) students trained on speed reading strategies. Pre and post reading comprehension tests were administrated. The results showed that the students in the experimental group were better than the students in the controlled group. The difference between the means was due to the use of speed reading strategies. In the light of the results, it is recommended that teachers should train students extensively on the use of speed reading strategies such as skimming and scanning.

Still relating to reading strategies, Fatmawati (2014) conducted a study to investigate the use of skimming and scanning in teaching reading of descriptive texts to Junior High School students in Lampung. The data came from two pre-test and two post-test in experimental group and control group. The results indicated that there is impact of using skimming and scanning strategies towards the students' reading comprehension.

From all mentioned studies relating to reading strategies, they noticed that there is an effect of using reading strategies such as skimming and scanning on students' achievement in reading comprehension and their speed rates as well. Skimming and scanning seem to be two terms which are very simple in reading strategies. However, both are able to give an important progress for readers to comprehend the texts instead of improving their speed of reading. Five aspects of reading below are treated by skimming and scanning as strategies of teaching reading in this study.

\section{Identifying purposes and organizational patterns of texts}

Through strategies of skimming and scanning readers are able to distinguish between the overall purpose of a passage and the purpose of specific parts of a passage, to identify category words that restate the purpose of a passage, to find out the organizational pattern of the passage by recognizing relationships between points made in the passage, and to 
recognize signal words in the passage and identify the organizational patterns they represent.

\section{Understanding unknown vocabulary from structural clues and word parts}

Barnhart (2008: 697) states that stock of words is used by person, class of people, profession. Concerning with those statements indeed vocabulary is fundamental for everyone who want to comprehend ideas in reading. Sometimes, on the passages, author used unknown or low frequency words to convey a meaning. By skimming types of structural clues such as words marked with punctuation, restatement, and examples, students are able to guess the meaning of unknown vocabulary in the very limited time. Instead of structural clues, scanning also helps students to understand how to find the meaning of unknown words through scrutinizing the word parts such as prefixes, suffixes, and roots contained within the word. This is the point, how to understand precisely unknown words (without using dictionary) in comprehending texts is badly needed by common readers.

\section{Inferring information from the passage}

In relation to make inferences, Katheleen (1986: 31) states that "an inference is an educational guess or prediction about something unknown based on available facts and information. It is the logical connection that the reader draw between he observed or known and what he does not know". The inference is usually used to predict what the topic discussed precedes and follows the text which is being read. Information given in reading texts is both directly stated and indirectly stated. Inference can be made through concluding or paraphrasing information. In addition, inference may make predictions about another related situation, such as what probably came 
before or after the reading passage. To this type of inference, readers only skim the first sentence or the last sentence of the passage. By inferring, again, skimming must have been the solution employed by readers to make time effective.

\section{Understanding facts and details from the text}

Two types of fact and detail provided on the reading task; those are about "what is true" and "what is not true" relating to the information given on the passage. To understand facts and details from the passage, scanning is a technique which can be taken for granted. Students should employ scanning by looking for the topic and main idea, because all facts, details, and the overall organization of the passage refers to the topic and main idea. Therefore, specific information will tell readers about the main idea precisely (Katheleen, 1986: 36). Thus, by scanning what should be scanned can help readers to speed their comprehension in this kind of reading task.

\section{Defining author's attitudes, tones, and purposes on the passage}

A reading task that asks about the attitude of the author or the tone of the passage requires that readers think about the whole passage. In some passages the author may express how he or she feels about the topic, the ideas, or the issues that he or she has written about. In this reading task, students who have no technique to understand author's attitudes, tones, and purposes, of course will spend much time to do this task. Again, skimming is the key to make time not wasted. Readers must skim the passage looking for clues that the author is showing some emotion in order to define author's attitude and the passage tone. In terms of author's purpose, readers may draw a conclusion about the purpose by skimming the main idea in the topic sentence and the details used to support the main idea. 
In relation to the focus of this study, strategies of scanning and skimming are used to achieve maximum comprehension through reading aspects aforementioned. In this regard, students are given an experiment on how to succeed with those aspects of reading comprehension through scanning and skimming strategies. There are two main objectives which want to find out: (1) to know whether skimming and scanning strategies are effective to improve students' comprehension in relation to five aspects of reading in comprehending the text; (2) to know whether skimming and scanning strategies are also effective to improve students' reading speed.

\section{RESEARCH METHODS}

This study used true experimental design taking the type of pre-test and post-test control group design. This research design used two groups to be compared: experimental group and control group which were randomly selected. Both groups were given a pre-test to find out their proficiency levels (before treatments) whether the two groups are different or not. The pre-test result was analysed using independent sample t-test statistical analysis. The test instrument was an academic reading test proficiency adapted from Reading Diagnostic Test based on Phillips (2001) which was regarded to be standard to the level of university students. There were 50 items to be tested which represented five aspect of reading proficiency as treated during five weeks of teaching. To confirm the vallidity of test, the researcher asked two senior lecturer of English education to rate the content of test. Both lecturers were agreed that the test content was suitable and could evaluate the students' ablities on reading comprehension. Then, Cronbach Alpha used to count the reliability coefficient was .81 . So, the researcher felt confident about the validity and the reliability of the test instrument. 
The subjects were taken from the third year EFL students of English Study Programme of Palangka Raya University that are considered to be passed the courses of Reading-1 (level one) and Reading-2 (level two). There were 54 students who were taking the course of Reading-3 (level three) taken as the sample which were equally in number to be grouped into two; experimental group and control group. The experimental group was the class of Reading-3 where the researcher supervised it, and the control group was the other class of Reading-3 where he did not supervise it with the experiment. Students on both groups were selected through random sampling method in order to meet number of 27 for each group where they had equal chances to be picked as the sample of this study.

The experiment treated was the teaching of reading using skimming and scanning strategies. There were five sessions of teaching reading implementing skimming and scanning strategies in the experiment based on material tested to the experimental group. The experiments covered five sessions implementing five aspects of reading comprehension during five weeks, those were Treatment-1: Identifying purposes and organizational patterns of texts; Treatment-2: Understanding unknown vocabulary from structural clues and word parts; Treatment-3: Inferring information from the passage; Treatment-4: Understanding facts and details from the text; and Treatment-5: Defining author's attitudes, tones, and purposes on the passage. After that treatment being completed, a test again was given to two groups of sample to find out the data from the group which was experimented (experimental group) and the group which was not experimented (control group). The data were statistically analysed referring to independent sample t-test to find out the effect of treatments given whether significant or not.

In addition, the researcher also administered the reading speed rates to both groups immediately after the pre-test and the post-test given. The 
students were given three different texts to be read in which each text had 400 to 600 words in length. The speed rate for each text performed by each student was calculated to find out the speed of reading into wpm (words per minute) unit. Then, the reading speed rate in average was accumulated through three texts attained by students in the respective group. Finally, the researcher summarized the speeds of reading performed by the two groups. In order to find out whether there is an improvement of the reading speed in relation to the experiment conducted, the result of the reading speed rates by both groups was also statistically analyzed by using independent sample of ttest.

\section{RESULTS \& DISCUSSION}

Before implementing treatments, the researcher administered a pretest to both groups to make sure that there is no difference in reading skill competence between the two groups. The following is the result of analysis related to mean scores of both groups on pre-test.

Table 1. Significance difference between the mean reading comprehension scores of experimental group and control group on pre-test

\begin{tabular}{cccccccc}
\hline \multicolumn{1}{c}{ Groups } & N & Mean & Sd & $\begin{array}{c}\text { Mean } \\
\text { difference }\end{array}$ & t & df & $\begin{array}{c}\mathbf{p} \\
\text { (2-tailed) }\end{array}$ \\
\cline { 1 - 4 } Experimental & 27 & 64.39 & 3.98 & \multirow{2}{*}{1.20} & 1.134 & 52 & .262 \\
\hline Control & 27 & 63.19 & 3.81 & & & & \\
\hline \multicolumn{2}{c}{ Table } & 1 & shows that & reading & comprehension & scores & were not
\end{tabular}

significantly different between the experimental group (M=64.39, $\mathrm{SD}=3.98)$ and the control group $(\mathrm{M}=63.19, \mathrm{SD}=3.81), \mathrm{t}=1.134, \mathrm{p}=.262$. This means that both groups are at the same level of reading proficiency before the treatments made. 
During five times of treatments carried out to the experimental group which spent five weeks to complete, the researcher gave a feedback at the end of each treatment to the groups by reflecting and feeding students with some exercises. The evaluation was not a measurement of the treatment, but it simply was a reflection for the researcher to evaluate his treatments whether they gave any benefit to the students or not. To find out precisely the result of the five treatments, the researcher conducted a test for the experimental group and also to the control group. The table below is the result of analysis related to mean scores of both groups on post-test.

\begin{tabular}{ccccccccc}
\multicolumn{7}{c}{ Table 2. Significance difference between the mean reading } \\
comprehension scores of experimental group and control group on post- \\
test
\end{tabular}

Table 2 shows that the experimental group had higher significantly reading comprehension scores $(\mathrm{M}=75.56, \mathrm{SD}=4.07)$ than the control group $(\mathrm{M}=64.82, \quad \mathrm{SD}=3.72), \mathrm{t}=9.928, \mathrm{p}=.000$, after five weeks treatments implemented to the experimental group. In fact, the result of post-test shows different achievements to both groups on reading comprehension where the experimental group seems to be improved much better than the control group. As a result, the treatments given to the experimental group succeed to improve students' reading comprehension.

This is to say that skimming and scanning strategies can afford to improve significantly students' comprehension in reading tasks in terms of (1) identifying purposes and organizational patterns of texts; (2) understanding unknown vocabulary from structural clues and word parts; (3) inferring information from the passage; (4) understanding facts and details 
from the text; and (5) defining author's attitudes, tones, and purposes on the passage.

Table 3. Significance difference between the mean reading speed rates (wpm*) of experimental group and control group on pre-test

\begin{tabular}{|c|c|c|c|c|c|c|c|}
\hline Groups & $\mathbf{N}$ & $\begin{array}{l}\text { Mean } \\
(\mathrm{wpm})\end{array}$ & Sd & $\begin{array}{c}\text { Mean } \\
\text { difference }\end{array}$ & $\mathbf{t}$ & df & $\underset{\text { (2-tailed) }}{\mathbf{p}}$ \\
\hline Experimental & 27 & 148.96 & 7.49 & \multirow{2}{*}{2.48} & \multirow{2}{*}{1.194} & \multirow{2}{*}{52} & \multirow{2}{*}{.238} \\
\hline Control & 27 & 146.48 & 7.77 & & & & \\
\hline
\end{tabular}

Table 3 depicts no significant difference between mean rates of reading speed performed by the experimental group ( $\mathrm{M}=148.96, \mathrm{SD}=7.49)$ and the control group $(\mathrm{M}=146.48, \mathrm{SD}=7.77), \mathrm{t}=1.194, \mathrm{p}=.238$. This data analysis showed that the speed rates of reading performed by students in the experimental and the control groups was not different or at the same level before treatments were carried out.

Again, to show whether strategies of skimming and scanning give significant effect to the speed rates of reading, Table 4 below depicts the result of reading speed rates performed by both groups.

Table 4. Significance difference between the mean reading speed rates (wpm*) of the experimental group and the control group on post-test

\begin{tabular}{lccccccc}
\hline \multicolumn{1}{c}{ Groups } & N & $\begin{array}{c}\text { Mean } \\
(\mathbf{w p m})\end{array}$ & Sd & $\begin{array}{c}\text { Mean } \\
\text { difference }\end{array}$ & t & df & $\begin{array}{c}\text { p } \\
(\mathbf{2}- \\
\text { tailed) }\end{array}$ \\
\hline Experimental & 27 & 274.07 & 32.06 & 69.78 & 9.325 & 52 & .000 \\
\hline Control & 27 & 204.29 & 21.98 & & & \multicolumn{2}{c}{ *wpm (words per minute) }
\end{tabular}


The data analysis showed that the speed rates of reading performed by the experimental group $(\mathrm{M}=274.07, \mathrm{SD}=32.06)$ was much better than that of performed by the control group ( $\mathrm{M}=204.29, \mathrm{SD}=21.98), \mathrm{t}=9.325, \mathrm{p}=.000$. This is to say, again, that skimming and scanning strategies are able to boost significantly students' speed rates of reading in completing the reading tasks.

In respect to the rates of reading speed test administered before treatments, the two groups only have $2.48 \mathrm{wpm}$ of speed rate mean difference. However, after treatments the two groups have $69.78 \mathrm{wpm}$ of the speed rate mean difference in which the experimental group again outperformed the control group. In relation to the speed of reading, Fry in Bell (2001: 1) states the rate per minute of reading speed for poor readers or below average is 150 to $249 \mathrm{wpm}$, then a reader having speed rates 250 to 350 wpm belongs to a good reader or above average level of speed rates. With respect to the student speed rates depicted in this research, the two groups have reading rates in range of 146-149 wpm before treatments where their levels are categorized as poor readers which are no difference between both. However, after treatments completed the experimental group has rates $274 \mathrm{wpm}$ of speed which belongs to the speed rate category of good level. In contrast, the control group only has rate of 204 wpm meaning the reading speed is still on the same rate level category as previously be depicted. To sum up, strategies of skimming and scanning enable students in the experimental group to raise their speed rates level of reading which is much better than the control group which has no any improvement of the rate level.

This research finding depicts that the improvement of comprehension in reading is correlated with the increase of reading speed rate. The result of this research reconfirm what Nunan (1999: 251) points out that "skimming and scanning both involve fairly rapid superficial reading and both are aimed 
at searching, rather than deep processing of the text or reflection upon the content of the text". This means one who has good speed rate of reading can precisely extract certain specific information without spending much time through the whole text. In addition, this research also supports Bell (2001) and Iwahori (2008) studies which revealed that after receiving treatment in reading tasks students improved their reading rate as well as general language proficiency.

\section{CONCLUSION}

Skimming and scanning strategies are effective to improve students' comprehension in the reading tasks. The increase of scores in experimental group indicates that treatments given to the group are proved being better to enhance reading comprehension than the control group. Besides, the experimental group shows more excellent performance in terms of reading speed rates than its counterpart where there is also a significant difference to both groups. To conclude, skimming and scanning strategies are efficient to minimize time consuming in the tasks of reading. Consequently, the researcher may speculate based on this finding that the faster students' performance in reading the better their comprehension in completing reading tasks.

\section{REFERENCES}

Abdelrahman, Mahmood SHB., and Bsharah, Muwafaq S. (2014). "The Effect of Speed Reading Strategies on Developing Reading Comprehension among the 2nd Secondary Students in English Language”. English Language Teaching. Vol. 7, No. 6; 2014. Canadian Centre of Science and Education. 
Bam ford, Julian and Richard R. Day. (2004). "Extensive Reading Activities for Teaching Language". Cambridge Handbooks for Language Teachers. Cambridge, England.

Barnhart, Cynthia A. (2008). The Facts on File Student's Dictionary of American English. Facts on File, Inc.

Beale, A. M. (2013). Anne Arundal Community College. Retrieved from www.aacc.ed/ tutoring/file/skimming.pdf

Bell, T. (2001). Extensive Reading: Speed and Comprehension. The Reading $\begin{array}{lllll}\text { Matrix, } & \text { [online]. } & \text { Vo.1 } & \text { (1): 1-13, retrieved from }\end{array}$ $\mathrm{https//www.readingmatrix.com/} \mathrm{[July} \mathrm{3,} \mathrm{2014].}$

Brown, H. Douglas. (1994). Teaching by Principles: An Interactive Approach to Language Pedagogy. Upper Saddle River, Prentice Hall Regents.

Brown, H. Douglas. (2001). Principles of Languages Learning and Teaching. New York: Pearson.

Casey, K. (2003). The Do's and Don'ts's for Improving Reading Comprehension. Retrieved from http://lteslj.org/technique.html

Djuharie, O. S,. (2008). Intensive Reading Bottom-up Reading. Penerbit Yrama Widya. Bandung.

Djuwarsih, (2006). Learning and Teaching Strategies. Penerbit Wijaya Saputra. Jakarta.

Fatmawati, Yuli. (2014). The Impact of Using Skimming and Scanning Strategies of Descriptive Text towards Students' Reading Comprehension at Grade Eight of SMPN 22 Bandar Lampung. Digital Library Universitas Negeri Lampung. Retrieved from http://digilib.unila.ac.id.

Hong, Ng Chiew. (2013). "Teaching of Skimming at Tertiary Level: Theoretical and Pedagogical Issues". Published on International 
Journal of Bilingual \& Multilingual Teachers of English. Vol. 1, No. 1, pp. 1-7. University of Bahrain.

Iwahori, Y. (2008). Developing Reading Fluency: A study of extensive reading in EFL. Reading in a Foreign Language. 20, 70-91.

Katheleen, Mc Whother. (1986). Guide to College Reading. Little Brown and Company.

Macleod, M. (2013). Types of Reading. Retrieved from fis.ucalgary.ca/Brian/611/ reading type.Html \#references.

McNamara, D. S., Boonthum, C., Levinstein, I. B, \& Millis, K. (2009). "Evaluating self-explanations in i-START: Comparing word-based and LSA algorithms" in Handbook of Latent Semantic Analysis. Psychology Press.

Murcia, Celce. 2001. Teaching English as a Second or Foreign Language.

Washington: Heinle and Heinle Thomas Learning Inc.

Nunan, D., (1999). Second Language Teaching and Learning. Heinz \& Heinz Publishers.

Nuttal, C. (1982). Teaching Reading Skill in a Foreign Language. New Edition. Heinemann Educational Book: Oxford University Press.

Phillips, Deborah. (2001). Longman Complete Course for the TOEFL Test. New York: A Pearson Education Company.

Rababa'h, G. (1991). The Effect of Using Skimming and Scanning on First Secondary Scientific Class Students' Achievement in Reading Comprehension (Unpublished M.A. thesis, Yarmouk University).

Simanjuntak, E. G. (1989). Developing Reading Skill for EFL Students. Jakarta: P2LPTK.

Souhila, Rouai. (2014). The Use of Reading Strategies in Improving Reading Comprehension: the case of first year LMD English students. 
Unpublished Master Thesis. Department of Foreign Languages. University Kasdi Merbah Ouargla.

Susanti, Meylinda. (2013). An Analysis of Students' Reading Comprehension Achievement by Using Scanning and Skimming Techniques for Introvert and Extrovert Students at SMPN 29 Bandar Lampung. Unpublished Sarjana Thesis. Teacher Training and Education Faculty. Universitas Lampung. Retrieved from http://digilib.unila.ac.id.

Vaezi, S. (2006). "Theories of Reading". In Language Institute Language Teaching Journal. Vol. I Spring 2005. Iran. 